\title{
Ius ad bellum i ius in bello u ranoj islamskoj civilizaciji
}

Nedžad Bašić**

\begin{abstract}
Sažetak
Ovaj članak ima za cilj povećati znanje o ranom islamskom međunarodnom pravu, uključujući znanje o prirodi islamskog ratnog prava u ranoj fazi islama. U članku se razmatra mogući pravni sukob između normi islamskog božanskog prava i islamske jurisprudencije kao posljedice tumačenja normi božanskog prava od strane čovjeka kao Božjeg agenta na zemlji. U tom potencijalnom pravnom sukobu članak razmatra interakcije između zakona rata i zabrane nasilja u islamu, što postaje iznimno važno za bolje razumijevanje "zatvorenoga kruga nasilja” u islamu, što je danas evidentno.
\end{abstract}

Ključne riječi: Akham al-Hiraba, Akham al-Bughat, Akham al-Tariq

\section{Uvod}

Cijela povijest islamske civilizacije obilježena je permanentnim obnovama (tajdid), reformama (islah) i renesansama (nahda). U najranijoj fazi islama bila je naglašena dimenzija socijalnog egaletarizma, odnosno jednakosti među ljudima, koja je posebno bila promovirana u govorima poslanika Muhameda, koji se zajednički nazivaju Hadisi (Hadith). S ekspanzijom islama u područja koja su naseljavali narodi s različitim kulturnim identitetima pojavila se potreba za još višim stupnjem fleksibilnosti islamskih kanona, što je dovelo do prave renesanse u reinterpretaciji Kurana i Sune (Sunnah), poslanikove prakse u islamu, odakle su proistekle različite škole islamske jurisprudencije, kao što su Hanafi, Hanbali, Maliki i Shafi'i u okviru Suna Islam te Jafari u okviru Šia (Shii) islama.

U islamu posebnu je važnost imalo razvijanje različitih socijalnih kategorija, kao što je kategorija zajedničkih dobara (maslaha ‘amma), kategorija samilosti ( rahma), kategorija ljudske dobrobiti (masali’h al- ibad), kategorija vjerskih manjina (ahl al-dhima), socijalne pravde ( $a d l$ ) i drugih brojnih socijalnih institucija

* Dr. sc. Nedžad Bašić, Centar za ljudska prava i prevenciju konflikta, Pravni fakultet, Univerzitet u Bihaću. Adresa: Ul. Mehe Hadžiabdića bb, 77000 Bihać, Bosna i Hercegovina.

E-adresa: nbasic.hrcpc@gmail.com 
koje su ocrtavale poseban identitet islama kao globalnog filozofsko-političkog i socijalnog koncepta, povezujući islam od najranijih dana njegova razvoja s filozofskim i humanitarnim konceptom ranog društva.

Kroz razvijanje načela konsensusa (ijmā) i metoda konzultacija u procesima odlučivanja šura (shürā), koji su utemeljeni na sustavu pravde (haqq), na sustavu kreativnosti (talfiq) i modelu rasuđivanja na načelu analogije kuranskih ajeta (kiyas), ijtihad (ijtihād), kao metoda interpretacije Kurana i nezavisnog odlučivanja, izrastao je u određujuću komponentu identiteta islamske kulture kao modernog političko-filozofskog koncepta demokracije (Smock, 2004).

Iz te brze unutarnje političke i socijalne vibracije islamskog društva izraslo je islamsko ratno pravo kao jedna od najvibrantnijih pravnih disciplina u islamskom pravnom sustavu. Brza socijalna i politička transformacija islama tražila je i bržu reformaciju filozofske misli i pravnih i moralnih načela islamskog imperija. Brze socijalne i političke unutarnje promjene bile su suočene s rigidnom i čvrstom pravnom strukturom islamskog pravnog sustava te su tražile fleksibilniji pristup tumačenju Kurana i prakse koja se je razvijala u djelovanju poslanika Muhameda - Suna (Sunnah). Da bi se razumjela i pomirila različita tumačenja kuranskih i sunetskih odredbi, razvila se je posebna škola asbab an-nouzoul, sa zadatkom proučavanja uvjeta pod kojima se ta tumačenja mogu razlikovati i uskladiti. Druga škola poznata kao Ijtihad ili inovacijska škola razvila se u skladu s potrebom za promjenom značenja nekih normi Kurana i Sune/Hadisa, ovisno o povijesnom razdoblju. Među prvima koji su drugačije tumačili Kuran i Sune/ Hadis, u različitim povijesnim uvjetima života muslimana, bio je kalif Omar ibn al-Khattab i imam Muhammed ibn Idriz al Shafi'i, i to samo 50 godina nakon poslanikove smrti. Te škole otvorile su novi prostor za komunikaciju između islama i drugih civilizacija, što je u velikoj mjeri pridonijelo većemu stupnju suživota pravnih i moralnih normi u ratnim sukobima između različitih civilizacija (El-Fadl, 2003).

\section{Ius ad bellum in Lex Islamica}

\subsection{Prerastanja normi islamskog prava u međunarodno islamsko pravo}

Priroda međunarodnog islamskog prava (Siyar), koje proistječe iz islamskog zakona šerijata (Shari'ah), koji regulira odnose između pojedinaca unutar islamske zajednice, kao i odnose između pojedinca i zajednice u islamu, problematična je među teoretičarima međunarodnog prava. Mogu li se odnosi u prvoj fazi susreta islama i kršćanstva smatrati rudimentarnim oblicima međunarodnih odnosa, danas je pitanje oko kojeg se vode velike rasprave u teoriji međunarodnih odnosa. Imajući u vidu da se normama međunarodnog prava mogu smatrati samo pravna pravila koja nastaju u međunarodnim odnosima, ta pravna rasprava duboko iritira i prirodu međunarodnog prava, uključujući i islamsko međunarodno pravo. 
$\mathrm{U}$ argumentaciji jedne grupe autora, $\mathrm{u}$ tom periodu nije postojala politička organiziranost društvenih grupa, kao država koje imaju svoje zajedničke interese i vrijednosti u međusobnim odnosima. Odnosi između zajednica prvenstveno su bili utemeljeni na vjerskoj i kulturnoj isključivosti, što eliminira mogućnost da se u tom periodu govori o međunarodnim odnosima (Walsh, 1922). Imajući u vidu da norme islamskog međunarodnog prava reguliraju odnose između islamskih država kao i odnose s neislamskim državama (dhimmiss), koji su bili limitirani na uža geografska područja, neki autori osporavaju međunarodno-pravni karakter normama međunarodnog islamskog prava, poentirajući da su te norme prvenstveno bile usmjerene na regulaciju odnosa između samih islamskih zajednica — država i neislamskih zajednica — država s islamskom državom u užim geografskim okvirima ne uspijevajući doći do razine opće prihvaćene norme globalnog pravila koje je prihvaćeno od međunarodne zajednice, osporavajući time međunarodno-pravni karakter tih normi (Khadduri, 1996, 2-3).

Ta grupa autora često ističe da u to doba nije bilo moguće govoriti o međunarodnim odnosima zbog odsustva tzv. zajedničkog interesa i zajedničkog sustava vrijednosti, iz kojih bi proistjecala zajednička pravila u odnosima između tih zajednica, koje se ne mogu uvijek definirati kao države u modernom smislu riječi, koje uživaju punu neovisnost, samoodređenje i koje uživaju pravo na samoodbranu, što čini njihov suverenitet neodređenim i varljivim. Zato ta grupa autora negira postojanje međunarodne zajednice u tom periodu, dakako i međunarodnih odnosa i normi međunarodnog prava, uključujući tu i norme međunarodnog islamskog prava.

Međutim, druga grupa autora u definiranju prirode odnosa između ranog islama i kršćanstva polazi prije svega od činjenice da se u tim odnosima razvijaju pravila, tradicije, običaji i ugovori kojima su regulirani odnosi između zajednica za vrijeme mira i rata, kojima se rješavaju sporovi, započinju i prekidaju ratovi, uspostavljaju savezi. Razvijaju se opće prihvaćena pravila zaštite pojedinih kategorija stanovništva u vrijeme ratnih sukoba, pravila međusobnog komuniciranja i vođenja pregovora, što je vodilo stvaranju i prvih oblika diplomacije. Pravi se razlika između politički organiziranih i teritorijalno međusobno razgraničenih zajednica te neorganiziranih barbarskih grupa s kojima su se uspostavljali jedino odnosi rata. Imajući u vidu da su u tom razdoblju odnosi između država objektivno zbog tehničkih ograničenja bili reducirani na uža geografska područja, tako da se je u tom periodu određenje međunarodne zajednice svodilo prije svega samo na odnose između država i zajednica koje su egzistirale u njihovu međusobnom saznanju, ti autori smatraju da bi se taj argument mogao teško koristiti u eliminaciji međunarodnih odnosa, dakako i međunarodnog prava u tom periodu (Harle, 1998, 139).

Ta grupa autora smatra da se za određenje karaktera moralne i pravne norme i običajnog pravila treba koristiti kriterij sposobnosti, odnosno vitalnost moralne i pravne norme i običajnog pravila, nadživjeti epohu svojega nastanka. U tom kontekstu teško bi bilo, smatraju oni, osporiti međunarodno-pravni karakter sustavu običajnih, moralnih i pravnih standarda koji su razvijeni u okviru međuna- 
rodnog islamskog prava u najranijem razdoblju islama (Hamidullah, 1996, 139). Zbog toga ta grupa autora smatra da je moguće odnose između ranog islama i kršćanstva promatrati u formi rudimentarnih međunarodnih odnosa, a institucije i pravila koja su se razvijala u tom razdoblju smatrati rudimentarnim normama međunarodnog primitivnog prava (Webster, 1975, 464 i 467). Zato se proces prerastanja normi unutarnjeg islamskog prava u međunarodno islamsko pravo, koje regulira odnose između islamskih i neislamskih država, kao i odnose između samih islamskih zemalja, može smatrati dijelom procesa stvaranja rudimentarnog međunarodnog prava, što neki teoretičari još uvijek osporavaju. Taj je proces još uvijek u tijeku i praćen je brojnim kontroverzama, kako u teoriji međunarodnog prava, tako i u praksi međunarodnih odnosa (Weeramantry, 1988, 132).

Za razvoj ratnog prava, u prvom razdoblju razvoja islama, od velike je važnosti bila vojna moć i intenzivno širenje islamskog imperija, koji je sve više ograničavao vojnu moć kršćanstva i kršćanskih država, ali je isto tako bivao ograničavan vojnom moći kršćanskih zajednica. S druge strane, islamski imperij izrastao je u moćnu civilizaciju, u okviru koje se razvijao novi sustav kulturnih, moralnih i pravnih normi, koje su direktno ili indirektno bile povezane s Kuranom kao svetom knjigom islama, u kojoj su bili regulirani brojni aspekti zaštite čovjeka u ratnim sukobima. Sublimacija imperijalne vojne moći, koja se je suočavala s moći drugih neislamskih imperija, i velikih duhovnih i kulturnih nadahnuća koja su se razvijala u okvirima islamske civilizacije i njezina doticanja s drugim imperijima i civilizacijama, ostavila je trag i na pravnim normama islamskog međunarodnog ratnog prava (Ghazi, 2006, 699-722).

Za razliku od stare grčke civilizacije i Rimskoga Carstva, koji na vrhuncu svoje moći nisu imali moćne vanjske protivnike, islamski imperij ni u jednom razdoblju svoje ekspanzije nije imao neograničenu moć svojeg djelovanja, što bi vodilo $\mathrm{k}$ aspiraciji uspostavljanja globalne duhovne dominacije. To je svakako imalo velik utjecaj na prve pravne norme i običaje ratovanja u islamu. Premda je islam, kao univerzalna religija, imao tendenciju širenja, kao i sve druge velike religije, njegova ekspanzija nije isključivo ovisila o vojnoj moći islamskog imperija, nego isto tako i o prihvatljivosti vjerskog, pravnog i moralnog kodeksa islama za narode koji su se nalazili u neposrednom dodiru s islamom. Time su do velikog izražaja došle odredbe Kurana o fleksibilnosti islama za sklapanje mira s neislamskim narodima koji ne žele rat te striktno poštivanje zaključenih ugovora o miru i nenapadanju s neislamskim zemljama, što se je moglo smatrati prvim začetcima diplomacije u okviru Lex Islamica. To je umnogom doprinijelo daljemu širenju islamskog humanitarnog kodeksa. Iz istih razloga i institut utočišta (asylum) bio je visoko razvijen u islamu.

Pitanje prirode odnosa između islamskih i neislamskih zajednica jedno je od najkontroverznijih pitanja u povijesti islama. O tom pitanju razvijeno je nekoliko dijametralno suprotnih stavova. Jedni su, pozivajući se na odredbe Kurana i praksu koja je implementirana za vrijeme života poslanika Muhameda i njegovih nasljednika, iznijeli tezu da je normalan odnos između islama i neislamskih zemalja odnos mira, a ne neprijateljstva i permanentnog rata. Pristalice toga gle- 
danja ne negiraju da je odnos islama i neislamskih zemalja u prvoj fazi razvoja islama predominanto bio odnos neprijateljstva i rata, što je bilo karakteristično za to razdoblje razvoja ljudske povijesti, ali da islam nije stanje permanentnog rata s neislamskim zajednicama tretirao kao normalno stanje (Ghazi, 2009).

Drugi su opet, pozivajući se također na odredbe Kurana (Qur'an 9:5), pronašli da su u samom Kuranu i praksi poslanika Muhameda odnosi između muslimana i nemuslimana odnosi međusobne isključivosti i neprijateljstva te da su odnosi između zemlje mira (dār al-Islām) i zemlje rata (dār al-harb) odnosi permanentnog rata i neprijateljstva (Ibn Khaldūn, 1958, 473).

Između ta dva koncepta u islamu razvijala se je velika teorijska rasprava, koja traje sve do današnjih dana. Pristalice koncepta permanentnog rata između islama i neislamskih zemalja smatraju da se odredbe Kurana koje se odnose na neprestanu borbu protiv poganstva i idolopoklonstva (Qur'an 9:5) neposredno odnose i na pripadnike drugih religija, dakako na sve nemuslimanske zemlje i narode (Qur'an 9:29).

Pristalice koncepta koji odbacuje tezu neprestanog rata između islama i neislamskih zajednica striktno prave razliku između odredbe Kurana kojom se naređuje permanentna borba protiv idolopoklonstva i odredbe Kurana kojom se naređuje borba (qital) protiv nemuslimana koji se nalaze na okupiranim područjima od strane islamskog imperija, koji odbijaju platiti porez (jizyah) islamskoj državi ili koji krše mirovne ugovore i vode agresiju prema islamskom imperiju.

Kako islam strogo poštuje sklopljene mirovne ugovore, u slučaju kršenja mirovnih ugovora od strane neislamskih zemalja i zajednica s islamskim imperijem ili s njegovim saveznicima, obveza poštovanja ugovora automatski prestaje, što dobiva značenje prava na odbrambeni rat, smatraju pristalice koncepta bellum iustum u Lex Islamica (Qur'an 9:13). Međutim, oni odbijaju te odredbe Kurana povezati s odredbama Kurana koje se odnose na borbu protiv ateizma i idolopoklonstva kao neprestanog prirodnog stanja rata u islamu (El Fadl, 2002, 3).

\subsection{Karakter normi islamskog međunarodnog prava}

Iako islamsko pravo prihvaća koncepciju personalnog (božanskog), a ne teritorijalnog (državnog) suvereniteta, odnosi unutar islama imaju veliku ulogu u razvoju filozofije i izvora javnog međunarodnog prava. Kako je jedino Bog suveren, on prenosi svoj suverenitet na pojedinca (čovjeka), a ne na grupu (vladu) koja bi mogla vladati u ime Boga, što otvara širok prostor za razvoj moderne demokratske misli u islamu. Iz toga slijedi da svaki pojedinac ne duguje odanost državi, nego isključivo Bogu, kojemu je izravno odgovoran. To ima za posljedicu odgovornost vlade/države narodu, što demokraciju u islamu čini ne samo kompatibilnom s konceptom suvremene demokracije, odnosno vladavine većine, nego izvornom i autentičnom demokracijom. To je imalo velik utjecaj na javno međunarodno pravo i međunarodne odnose (El Fadl, 2003, 14).

Koncept personalnog (božanskog) suvereniteta, prema kojem je Bog vrhovni suveren s prijenosom suverenosti na sve svoje podanike i čiji se apsolutni personalni božanski suverenitet prostire tamo gdje žive muslimani, čini odnose između 
samih islamskih zemalja dosta nestabilnim, što je izazivalo brojne probleme i sukobe kroz povijest islama. Brojni ratovi između islamskih nezavisnih država, kao i sukobi brojnih plemenskih grupa unutar islamskih zemalja, tražili su jasnu pravnu regulaciju odnosa između vrhovnog božanskog autoriteta i autoriteta vladara autonomnih islamskih zajednica (država) i samih Božjih podanika. Za poznatog islamskog pravnika Abu Bakra Božji je suverenitet prenijet na autoritet lokalnog vladara koji upravlja islamskom zajednicom (državom) u ime svih muslimana koji žive u toj zajednici (državi), a njegov je autoritet neupitan sve dok slijedi Božje naredbe. Takav stav jednog dijela islamske jurisprudencije imao je kontraverzne implikacije na dalji razvoj islamske pravne misli, gdje je pravo na pobunu protiv vladara upitno (Athamina, 1999, 76).

Kako je islamski koncept personalne (Božje) suverenosti univerzalan, sve pravne, političke, diplomatske i vojne aktivnosti islamskih država regulirane su u skladu s jedinstvenim islamskim pravnim i moralnim kodeksom kao krajnjim izrazom Božjeg univerzalnog suvereniteta i najviše Božje volje, kojoj se treba podrediti volja i ponašanje kako svih muslimana pojedinaca, tako i državnih vladara islamskih zemalja. Pravni temelj takvog stava pripadnici Hanefijskog mezheba (pravne škole) nalazili su u ranim dogmatskim stavovima al-Fiqh al-Absat Abu Hanife (699.-767.), koji je bio osnivač i najistaknutiji zastupnik te škole. Posebno su zanimljivi stavovi te pravne škole u kontekstu izražene kritičnosti prema postupcima vlasti. Iako se u osnovi oslanja na dogmatsko učenje, Hanefijski mezheb proglasio je vjerskom dužnosti svakog muslimana boriti se za ono što je ispravno i zabraniti vlastima da čine ono što je neispravno.

U dokazivanju što je ispravno a što neispravno u postupcima vladara, ta je škola uvela sučeljavanje kao metodu dokazivanja, što je otvorilo put pravu na pobunu protiv vladara koji postupa neispravno i koji se smatra "grešnim vjernikom". Pravo na pobunu protiv vladara kao "grešnog vjernika", iako eksplicitno nije bila dopuštena vojna pobuna, nego prije svega kritika vladara, kako je tumačio Abu Hanifa, imalo je revolucionarne posljedice za dalji razvoj moralne i političke misli u islamu (Cook, 2000).

U islamskoj pravnoj teoriji, u kojoj je nesporan vrhovni autoritet normi božanskog prava, često je dolazilo do pravnog nesporazuma po pitanju odnosa između načela božanskog prava, s jedne strane, i normi islamske jurisprudencije, s druge strane, kao pravnih pravila nastalih tumačenjem božanskog prava od strane čovjeka, gdje uvijek postoji mogućnost ljudske greške u tumačenju značenja i primjene božanskog prava. Na rješavanju tog problema nastale su dvije pravne škole. Po shvaćanju jedne od tih škola themukhatti'ah, zakon koji primjenjuje država samo je potencijalno Božji zakon te je podložan provjeri i osporavanju. Po shvaćanju druge škole musawwibah, zakon koji primjenjuje država nije podložan provjeri i osporavanju, osim ako osoba na koju se taj zakon primjenjuje smatra da to nije Božja volja i zapovijed (El Fadl, 2003, 61).

$\mathrm{S}$ takvim tumačenjem dana je apsolutna prevaga islamskomu božanskomu pravu (Kuran, Hadis/Suna) nad islamskom jurisprudencijom (sharia i fiqh), što 
pobunu protiv države (vladara) čini dopuštenom i obveznom ako su odredbe jurisprudencije u suprotnosti s božanskim islamskim pravom (Lewis, 2005).

Na rubu pravnog razgraničenja između božanskog prava i jurisprudencije javio se veliki pravni sukob u islamskoj pravnoj misli, koji umnogom utječe kako na političke odnose unutar islama, tako i na odnose između islama i reprezentativne demokracije. Moralna moć reprezenatativne demokracije leži u ideji suvereniteta naroda kao glavnog izvora prava. U islamu suverenitet pripada isključivo Bogu. Bog ultimativno predstavlja jedini izvor prava. Kuran, Hadisi i Suna čine načela i postulate božanskog islamskog prava. Temeljno je načelo islamskog prava da zakon, koji je djelo čovjeka, ne može proturječiti autoritetu Boga. Ta konceptualna razlika između moderne reprezentativne demokracije i islama otvara pitanja odnosa islama i demokracije, islama i države, kao i pitanje odnosa vladara i pojedinaca (naroda) u islamu, na koje je prenijet suverenitet Boga na zemlji.

Generalna postavka da je moderna reprezentativna demokracija utemeljena na "sekularizmu" otvara izuzetno kompleksna teološka, filozofska i pravna pitanja odnosa između države i religije. Sekularno uređenje podrazumijeva odvajanje religije i države, što podrazumijeva tzv. "principijelnu distancu". Ta "principijelna distanca" uključuje tri distinktivne kategorije sekularnog uređenja: sloboda, jednakost, bratstvo (liberty, equality and fraternity). U širem smislu ta tripartitnost uključuje slobodu vjerovanja ili nevjerovanja, slobodu prakticiziranja religije, jednakost između religija, harmoniju između različitih religija i dr., što je temelj reprezentativne demokracije.

Postoje li distinkcije između tih načela reprezentativne demokracije i načela i postulata islamskog božanskog prava središnje je pitanje u razmatranju odnosa između islama i demokracije. Premda u islamu ne postoji razvijen koncept političkog sustava, postoji nekoliko načela i postulata u Kuranu na kojima se uspostavlja koncept vladanja u islamu: 1. uspostavljanje pravde kroz socijalnu saradnju i međusobnu asistenciju; 2. uspostavljanje neautokratskog i konzultativnog načina vladanja; 3 . institucionalizacija milosrđa i suosjećajnosti u društvenim odnosima.

Između reprezentativne demokracije $\mathrm{i}$ gore navedenih načela i postulata $\mathrm{u}$ Kuranu vidljiva su brojna preklapanja, što otvara zanimljivo pitanje odnosa islama i demokracije. Načela slobode, jednakosti i bratstva izravno su ili neizravno naznačeni u Kuranu, gdje piše da je Bog stvorio ljude različite i grupirao ih u različite narode i plemena da bi mogli upoznati jedni druge. Ta odredba Kurana indicira potrebu harmonije i jednakosti među ljudima, grupama, plemenima i narodima kako bi se dosegnula pravda kao božanski imperativ i reprezent božanskog suvereniteta. U Kuranu je također eksplicitno podržana potreba harmonije između različitih religija. Na jednom mjestu u Kuranu navodi se da kada bi cijelo čovječanstvo bilo pretvoreno u jedan narod (jednu vjeru), to ne bi prekinulo svađu među njima (Qur'an, 11:118). S tim se ističe nužnost postojanja i poštovanja različitosti među ljudima i religijama (El Fadl, 2003, 43).

Međutim, ta kompatibilnost između islamskog božanskog prava i reprezentativne demokracije dobrim dijelom nestaje u interpretaciji i primjeni božan- 
skog prava od strane čovjeka kao Božjeg agenta na zemlji te tu nastaje velik ne samo teološki, nego i pravni i politički problemi u islamu. Tu je vrlo bitno praviti razliku između načela i postulata islamskog božanskog prava i normi islamske jurisprudencije, koje nastaju tumačenjem normi islamskog božanskog prava od strane čovjeka, kao i tumačenjem tradicija i običaja islama (Schacht, 1959).

Za poznatog islamskog reformističkog teologa Khaleda Aboua El Fadla šerijat, premda čini samu srž islamskog zakona, nije u cjelini božansko pravo, koje čini glavni izvor šerijata. Kako šerijatski zakoni proistječu iz božanskog suvereniteta i kako se kreiraju u procesu analognog razmišljanja (kijas) i pravog konsenzusa (idžma) u procesu islamskog teološkog tumačenja (mudžtehid), on s pravom smatra da šerijat najvećim dijelom čini ljudsku idealnu interpretaciju božanske suverenosti. Obveza života u skladu s Božjim suverenitetom (pravom), koji je nepromjenljiv i besprijekoran, a koji se manifestira kroz idealnu interpretaciju (zakon) od strane čovjeka, kao Božjeg agenta na zemlji, ostavlja prostor za ljudske greške u interpretaciji, što proizvodi brojne probleme u islamskom pravu i praksi (El Fadl, 2003, 64).

\subsection{Uzrok rata u islamu (illat al-qitāl)}

Uzrok je rata jedno od važnih pitanja u islamskom pravu od prvih dana nastanka islamske civilizacije. Regulaciju odnosa između islama i neislamskih zemalja susrećemo u najranijim danima islamske civilizacije u radovima poznatih islamskih pravnika, prije svega Abu Hanife (Abū Hanīfah) i Muhameda Šabania (Muhammad ibn al-Ḥasan Shaybān̄i). U prvim danima razvoja islamske civilizacije rat je najčešće povezivan s džihadom kao ratom koji je vođen protiv poganskih plemena nevjernika (kufr, infidelity). Kompletnu doktrinu džihada u islamskom pravu prvi je razvio Muhamed Šafi (Mohammad ibn Idrīs al-Shāfi'ī) 820. godine, koji je definirao džihad kao kolektivnu obvezu svih muslimana da vode permanentni rat protiv nemuslimana i nevjernika (agana, infidels), ne samo u slučaju njihova napada na islamsku državu, kako je to zapisano u Kuranu (Qur'an 9:5), nego općenito (Al-Shafi‘i, 2001).

Takav radikalan stav određenja džihada po kojem se odnos između islamskih i neislamskih zemalja tumači kao permanentno neprijateljstvo nešto kasnije bio je modificiran od strane islamskih pravnika, koji su odbaciti takvo rigorozno i radikalno doslovno tumačenje odredaba Kurana. Ta grupa islamskih pravnika polazi od tumačenja samog teksta Kurana, kao i tumačenja ponašanja poslanika Muhameda, koje je on prakticizirao u odnosima s neislamskim zajednicama. Oni smatraju da je prakticiranje primanja poreza (jizyah) od neislamskih zajednica koje su ostale živjeti na osvojenim teritorijama od strane islamskog imperija značilo davanje odobrenja tim zajednicama da nastave s prakticiranjem svoje religije uz istovremeno preuzimanje obveza islamske države da jamči slobodu članova neislamske zajednice, zaštitu njihove imovine, što je rezultiralo smanjenjem otpora neislamskih zajednica prema islamu. Očigledno je takav pristup bio potaknut političkim i komercijalnim interesima islama u datom okruženju u kojem 
se je tada nalazio islamski imperij, što potvrđuju i neki povijesni dokumenti (AlTabari, 1992).

Sličan stav zauzeo je i Hanefijski mezheb, koji je odbacio svaku ideju da se borba protiv nevjernika može smatrati pravednim uzrokom rata u islamu. Ta pravna škola dobila je ime po poznatom islamskom pravniku Abu Hanifi i njegovim sljedbenicima Abu Jusufu i Al-Šabaniju (Muhammad al-Shaybani). Sljedbenici te škole smatrali su da islamska jurisprudencija poznaje samo odbrambeni rat u slučaju agresije na islamsku zemlju. Otuda se agresija, kao i u Lex Romana, smatra pravednim uzrokom vođenja rata. Da bi se rat protiv neislamske zajednice mogao smatrati pravednim ratom, napad na islamsku zemlju mora dolaziti izvana i mora biti stvaran i proveden ne od strane pojedinca, nego od organizirane grupe, što se može smatrati agresijom. Samo napad od organizirane grupe izvana, koji je usmjeren na najvažnije, najbitnije i najvitalnije objekte od kojih ovisi dalje egzistiranje islamske zajednice, kao što su vjera, život, osjećanje, porod i vlasništvo, smatraju se agresijom po islamskom pravu (Kallāf, 1978, 200).

Ubijanje nevjernika za vrijeme neprijateljstva između islamskih i neislamskih zemalja nije glavni cilj islama. Glavni je cilj obrana islama. Agresija na islam i islamsku zemlju od strane neislamskih zajednica i samodbrana islamske zajednice može se smatrati pravednim uzrokom rata, a ne nikako ubijanje ili protjerivanje nevjernika samo po sebi, smatraju pristalice te škole (Al-Tabari, 1992). Tako je i veliki islamski pravnik Al-Šabani, kojeg u islamu smatraju utemeljiteljem islamskog međunarodnog prava (Siyar), u svojem poznatom radu Kitab al-Siyar al-Kabir odredio da cilj džihada (Haqiqat ul-Jihad) doseže samo do postizanja sigurnosti za muslimane i do slabljenja oružane sile neprijateljske vojske. Kada se ta dva cilja ispune daljnja uporaba sile u islamu nije dopuštena.

Slično mišljenje dijele i drugi brojni islamski pravnici, koji u svojoj argumentaciji navode da bi u slučaju opravdanja ubijanja nevjernika radi širenja islama tada bila besmislena zabrana ubijanja žena i djece u neprijateljstvu između islamskih i neislamskih zajednica.

\subsection{Dār al-Islām i Dār al-Harb}

Iako suština islamskog međunarodnog prava proizlazi iz temeljnog univerzalnog načela islamskog prava da suverenost na zemlji pripada samo Bogu, islam priznaje paralelno postojanje neislamskih nezavisnih država i priznaje uspostavljanje ravnopravnih odnosa s neislamskim zemljama koje preferiraju miroljubivu politiku, poštujući ugovore koji su sklopljeni s tim zemljama. Većina islamskih pravnika smatra da odnose s neislamskim zemljama islam postavlja odnos neprijateljstva (rata) samo ako postoji tendencija neislamskih zemalja da uspostave dominaciju nad islamskim zemljama i da uspostave neravnopravnost vjera. Zato islam svaku državu koja pretendira uspostavljanju dominacije nad "suverenitetom islamske države" smatra neprijateljskom državom (Hamidullah, 1996, 88). 
U nešto kasnijem razdoblju razvoju islama, u doba slobodnog tumačenja u tzv. razdoblju idžtihada, neki islamski pravnici za zemlje koje su se nalazile pod dominacijom islama počeli su koristiti izraz Dār al-Islām, a za zemlje koje se nisu nalazile pod dominacijom islama koristili su izraz Dār al-Harb, koje se nalaze u permanentnom neprijateljstvu s islamskim imperijem, što je sugeriralo postojanje misije univerzalne dominacije islama i permanentnog rata, odnosno neprijateljstva islama s neislamskim zemljama (Al-Mawardi, 1996, 60).

Podjela na Dār al-Islām i Dār al-Harb podrazumijevala je u prvo vrijeme integriranje islamskih zemalja u jednu cjelinu, što je imalo za posljedicu brojne pravne i političke probleme. Međutim, jedna grupa islamskih pravnika na čelu s Abu Jusufom i Al-Šabanijem smatrala je da ta podjela ne znači i teritorijalnu integraciju i povezivanje svih islamskih zemalja, nego prije svega jamčenje sigurnosti muslimana i primjenu islamskog prava tamo gdje žive muslimani. I jedna i druga koncepcija vidi podjelu na Dār al-Islām i Dār al-Harb kao dva teritorija koji su međusobno u potencijalnoj, ali ne i u nužnoj konfrontaciji i sukobu (Uthman, 1983).

Brojni islamski pravnici, među kojima je i najpoznatiji Al-Šabani, te termine ne koriste neprestano, ostavljajući time mogućnost uspostavljanja i drugih odnosa između islama i neislamskih zemalja. Kao potvrdu svojeg stava da islam ne uspostavlja odnos neprijateljstva s nemuslimanima, oni najčešće navode zaštićen položaj nemuslimana na području Dār al-Islām, garanciju slobode prakticiziranja njihove religije, slobodu putovanja u područja koja nisu pod kontrolom islama, kao i slobodu obavljanja komercijalnih poslova na tom teritoriju. Međutim, samom činjenicom kvalificiranja teritorija koji nisu pod kontrolom islama kao neprijateljskog teritorija ostavljena je mogućnost za vođenje rata kada se procijeni da je Dār al-Harb dovoljno slaba da ne može izdržati pritisak Dār al-Islām, što sugerira da je islam u tom razdoblju, a to je razdoblje velike ekspanzije islama (oko 800. godine) nastojao restriktirati pravna ograničenja za vođenje osvajačkih ratova.

U prilog toj tezi ide i stav velikog islamskog pravnika Abu Hanife, koji muslimane zatečene u Dār al-Harb oslobađa svake odgovornosti za krađu i ubojstva počinjena na teritoriju izvan kontrole islama, ako to ima efekt slabljenja moći neprijateljske (neislamske) države. Po tom tumačenju muslimani su odgovorni samo islamskoj državi i imaju se ponašati samo u skladu s islamskim pravom bez obzira gdje se nalaze, čime je dana prednost konceptu personalnog (Božjeg) suvereniteta nad konceptom teritorijalnog suvereniteta države, čime se otvara pravna mogućnost ekspanzije islama.

U ranom islamu poznat je i institut tzv. dōr al-sulf ili dar al-'ahd (teritorija pod ugovorom). Tim pravnim institutom priznaje se nezavisnost neislamske zemlje pod uvjetom da plati godišnji porez, čime je, kako smatraju jedni teoretičari islamskog prava, de facto osporena samostalnost i neovisnost neislamskih država, odnosno prihvaćena je podjela na Dār al-Islām i Dār al-Harb, s permanentnim ratnim stanjem, s ciljem stjecanja nadmoći nad neislamskim državama kao univerzalnom misijom islama (Ibn Khaldūn, 1958, 473). 
Međutim, jedan broj islamskih pravnika smatra da je ta podjela proistekla ne iz Kurana, nego prije svega iz idžtihada, zbog čega se to smatra samo privremenim povijesnim stanjem, koje je bilo uvjetovano sukobima između islama i neislamskih zajednica u ranom periodu. Pozivajući se na odredbe Kurana, oni odbacuju koncept podjele na Dār al-Islām i Dār al-Harb, a samim tim i koncept permanentnog neprijateljstva između muslimana i nemuslimana. Ističu da Lex Islamica u prvi plan stavlja odnos tolerancije između islama i neislamskih zemalja, sve dok se takav odnos prakticira od strane neislamskih zemalja i nemuslimana, što po njima ima značenje uspostavljanja reciprociteta odnosa između islamskih i neislamskih zajednica (El Fadl, 2002, 22 i 25).

\section{Ius in bello in Lex Islamica}

\subsection{Islamsko pravo i rat}

Iako islam zabranjuje agresivni rat, $\mathrm{u}$ islamskoj pravnoj terminologiji razlikuju se tri tipa rata: rat protiv strane neislamske bezbožničke države - infidels (Akham al-Hiraba), rat protiv pobunjenika unutar islamskog imperija (Akham al-Bughat) i treći dopušteni vid uporabe sile je rat s ciljem jačanja islamskog prava (Akham al-Tariq).

Slično kao kod starih Grka i Rimljana, gdje je odnos s barbarskim plemenima promatran u svjetlu permanentnog rata, tako i u ranom islamu odnos između islama (Dār al-Islām, kuća mira i harmonije) i neislamskih zemalja (Dār al-Harb, kuća rata) promatran je u percepciji permanentnog rata. U sukobu između $D \bar{a} r$ al-Islām i Dār al-Harb jedna grupa povjesničara prava smatra da u islamu ne postoji institut pravednog rata, da se deklaracija (objava) rata smatra neobveznom te da se mogućnost zaključivanja stalnog mira s neislamskim državama isključuje. Međutim, druga grupa autora, pozivajući se na odredbe Kurana (Quran, 9:4 i 9:7.) i praksu poslanika Muhameda, u kojoj se susreću brojni primjeri prekida rata i apstinencije neprijateljstva između islamske i neislamskih zajednica (država), gdje islam preferira održavanje mira, sve dok održavanje mira prihvaća druga strana (država), odbacuje percepciju permanentnog rata u odnosima između islamskih i neislamskih zajednica (država).

U slučaju nastavljanja prekinutog rata (neprijateljstva), islamsko pravo predviđa obvezu obavještavanja neprijateljske strane o nastavljanju neprijateljstva. Institutu obustave neprijateljstva, koji je u islamskom pravu poznat kao Dar al-Sulh ili kuća sporazuma (Dar al-'Ahd), pravni je instrument (norma) koji je prvenstveno unilateralno regulirao odnose između islamskog imperija i neislamskih zemalja. U skladu s normama Dar al-'Ahd, za vrijeme prekida neprijateljstva, od neislamskih država, da bi izbjegnule nastavak neprijateljstva, traženo je da u intervalu prekida rata plaćaju porez islamskom imperiju, čime su se stjecale mogućnosti da njima upravljaju njihovi vladari, da bi na taj način ostale u miru. Taj oblik "kupovine mira" često je pratio i institut garancije slobode (aman) pojedincima neislamske zajednica, što je s vremenom preraslo u mogućnost garan- 
cije slobode cijelim neislamskim zajednicama, gradovima ili državama od strane vjerskih islamskih vladara imama, koji su svoju odluku po tom pitanju donosili u formi naredbe zvane berat (Shaw, 2006, 163).

Permanentni oblik neprijateljstva između Dār al-Islām i Dār al-Harb, u islamu poznat kao Akham al-Hirabah, posebno se je izražavao kroz permanentne upade, pljačke i razaranja neprijateljskih država od strane islamskih ratnika, koji su bile organizirani od strane pojedinaca a ne države. Taj oblik rata poznat je pod nazivom razzia, a organiziran je od strane specijalnih ratnika zvani gazije (ghazis), koji su često služili ili za odbranu ili proširenje granica islamskog imperija. Upadi i razaranje gazija na teritorijima susjednih država često su bili strategija provociranja i slabljenja države koju je islamski imperij planirao anektirati. Poznato pleme ratnika gazija bili su Osmanlije (Osmanlis), koje su toliko ojačali da su kasnije uspostavili Osmansko Carstvo, jedan od najvećih islamskih imperija.

Drugi je oblik vođenja rata u islamu džihad. Sama riječ džihad (Jihad), koja je arapskog podrijetla, nije ekskluzivno vojne, nego prvenstveno religiozne konotacije, koja ima izvorno značenje borbe na Božjem (Alahovu) putu za prosperitet pojedinca i islamske zajednice (El Fadl, 2002, 19). U povijesti islama često su se pod formom džihada vodili ratovi iz političkih ili komercijalnih razloga, što je uključivalo i oružanu borbu protiv neislamskih zajednica (Al-Mawardi, 1996). To je aktualiziralo pitanje tinjajućeg pravnog konflikta između "Božje suverenosti” (Kuran, Hadisi, Suna) i ljudske interpretacije božanske suverenosti i njezine primjene.

Za razliku od permanentnog rata s ateističkim plemenima koja žive izvan islamske države, kao i rata s neislamskim državama, odnos prema neislamskim zajednicama koje žive unutar islamskog imperija bio je temeljen na odnosima tolerancije u okviru kojih neislamski narodi nisu prisiljavani prihvatiti religiju islama, uz mogućnost zadržavanja svoje religije i uz obvezu uzdržavanja od vojnih pobuna u islamanskoj zajednici, nemogućnosti učešća u javnim poslovima islamske države i uz obvezu plaćanja specijalnog poreza islamskoj državi (Khadduri, 1979, 162-170).

U slučaju vojne pobune (baghy) islamska država imala je pravo povesti borbu protiv pobunjenika. Vojna je pobuna prvenstveno vezana za grupu koja je organizirana na određenom dijelu teritorija islamske države i koja ima neke od prerogativa vlade, što se uvijek ne vezuje za pobunu neislamskih zajednica u islamskoj državi (El Fadl, 2001, 235).

Islamski pravnici razlikuju tri vrste unutarnjih neprijatelja protiv kojih islamska država ima pravo voditi borbu (qital). Protiv kriminalnih grupa islam poznaje borbu zvanu muharib, protiv onih koji su napustili islam kao religiju (apostates) murtaddun i protiv političkih pobunjenika bughah. U svakoj od tih vojnih akcija postoji različit niz ograničenja. Tako na primjer u murtaddun islam dopušta ubijanje apostasa čak i kada su se odrekli svojih heretičkih stavova i položili oružje. U vojnoj akciji muharib za pripadnike kriminalnih grupa i pljačkaša islamsko pravo nema mnogo milosti. Dopuštena je amputacija ruku, nogu i drugi oblici sa- 
kaćenja za počinjeni zločin. Zato u okviru muhariba i murtadduna nema mnogo prostora za neka ograničenja uporabe sile i brutalnosti.

Za razliku od tih oblika uporabe vojne sile gdje su brutalnosti često vidljive i prisutne, u ratu protiv pobunjenika bughah susreću se brojna ograničenja u postupanju prema pobunjenicima. U skladu s islamskim pravom zabranjeno je ubijanje pobunjenika poslije njihove predaje. Zabranjeno je njihovo sakaćenje. Zabranjeno je njihovo istrebljivanje, što je imalo značenje zaštite članova obitelji pobunjenika. Zabranjeno je pretvaranje pobunjenika u robove. Njihovo otkupljivanje ili konfiskacija njihove imovine od strane pojedinaca u ratu nije bilo dopušteno (El Fadl, 2001, 32).

\subsection{Položaj ratnih zarobljenika u Lex Islamica}

Pitanje sudbine ratnih zarobljenika i odnos prema njima u islamu često je bilo različito tumačeno, što je dovodilo do brojnih nejasnoća i kontradiktornosti (Ghazi, 2006).

Mada Kuran poznaje status ratnih zarobljenika, kontroverzu izaziva uzimanje zarobljenika u slučaju da to ne vodi slabljenju protivnika u bitci. Jedni smatraju da je odredbom Kurana (Qur'an 47:12) zabranjeno zarobljavanje protivničkih vojnika sve dok bitka traje (život neprijateljskog vojnika i zarobljenika ne može se poštedjeti, rat bez zarobljenika je rat za pobjedu islamske vojske), a drugi smatraju da ta odredba Kurana, koja je prvenstveno imala za cilj podizanje borbenog duha islamskih ratnika, ne znači i zabranu zarobljavanja i uzimanje otkupa za zarobljene ratnike.

Poznati su brojni slučajevi oslobađanja ratnih zarobljenika bez otkupa pod obvezom da se više ne smiju boriti protiv muslimana. U slučaju da oslobođeni zarobljenik ne poštuje danu obvezu, njegov život, u slučaju ponovnog zarobljavanja, ne može biti ponovo pošteđen. Poznati su slučajevi i razmjene ratnih zarobljenika. Neprijateljski vojnik koji se je predao pod garancijom zaštite dane od strane vojnika islamske vojske ne smije biti pogubljen.

U Kuranu je sistematski razvijen "zakon rata" koji strogo zabranjuje ubijanje žena, djece i starih ljudi u ratnim sukobima, zabranjuje razaranje okupirane zemlje, spaljivanje kuća, i oduzimanje dobara od neprijatelja ako to ne zahtijevaju ratne potrebe. Zabranjuje se sprječavanje opskrbe vodom neprijatelja, zahtijeva se milosrdan odnos prema ratnim zarobljenicima, uz strogu zabranu njihova ubijanja bez naređenja. Uvodi se pravilo razmjene ratnih zarobljenika i otkupa ratnih zarobljenika (released on ransom). Ubijanje ratnih zarobljenika u islamu, kako povijest bilježi, generalno nije prakticizirano. Njihovo ubijanje bilo je dopušteno samo u izuzetnim slučajevima kada je riječ o teškim djelima protiv islamske države, kojima bi se mogao dovesti u pitanje njezin opstanak i ugled. U tim slučajevima naređenje za egzekuciju ratnih zarobljenika bilo je u rukama islamske vlade (imama), a ne pojedinaca ili vojnih komandanata (Qur'an 2:190).

Strogo je zabranjeno sakaćenje neprijateljskih vojnika i zarobljenika, ubijanje vjerskih službenika, starih i nemoćnih koji nisu mogli sudjelovati u neprijateljstvima, kao i seljaka koji rade u poljima, trgovca, opskrbljivača vodom i hranom, 
slijepih, hendikepiranih, kao i onih koji žive svojim zasebnim životom (asketi). Zabranjeno je ubijanje civilnih službenika u neprijateljskoj vojsci koji ne sudjeluju i nisu sudjelovali u borbi, koji ne vode propagandu i nisu učestvovali u propagandi i koji nisu špijuni. Njihovo ubijanje bilo je zabranjeno kako za vrijeme borbe, tako i u zarobljeništvu. U slučaju da te osobe pružaju logističku podršku neprijateljskoj vojsci, bez direktnog učešća u ratnim sukobima, odredbe islamskog ratnog prava, po jednom tumačenju u islamskoj pravnoj doktrini, ne odnose se na njihovu zaštitu, a po drugom tumačenju, koje podupire ponašanje poslanika Muhameda, smatra da se odredbe o zaštiti onih koji ne sudjeluju u neprijateljstvu odnose i na tu kategoriju ljudi (Peters, 1996, 49).

Ratni zarobljenici nisu mogli biti lišeni prava na hranu, vodu i odjeću (Qur'an 76:8). Žene i djeca neprijateljskih vojnika nisu ubijani i po pravilu nisu postajali robovi, s izuzetkom kada nisu imali nekog tko ce preuzeti brigu o njima. Žene i djeca mogli su biti oslobođeni uz otkup ili bez otkupa. Žene s malom djecom uživale su poseban status i kao takve nisu mogle biti prodane kao roblje. Žene čiji je gospodar umro postajale su slobodne (Pictet, 1985, 6-18). Muslimani nisu mogli biti u statusu roba. Međutim, robovima je bilo dopušteno prihvaćanje islama. Prihvaćanjem islama gubio se je status roba, što je izazivalo velike kontroverze po pitanju prirode mirnog i nenasilnog prihvaćanja islama.

Infrastruktura koja služi civilnomu stanovništvu ne smije biti razarana i uništena. Pojedini dijelovi te infrastrukture mogu biti predani na korišćenje ratnicima, ali samo za vrijeme vođenja neposrednog ratnog djelovanja, i moraju biti vraćeni zajednici od koje su izuzeti čim se ratno djelovanje privede kraju. Ta je praksa iz ranog razdoblja islama kasnije bila kolektirana i kodificirana u knjizi poznatoj kao Al-Wathaiq al-Siysiyah.

Za svaku štetu koja je nanesena ratnim zarobljenicima odgovorna je islamska država, koja je obvezna ostvariti punu sigurnost za ratne zarobljenike i za njihovo odvođenje na sigurno mjesto (Al-Zarqa, 1968, 1085).

Islam dopušta kršćanima i židovima život $\mathrm{u}$ islamskim zemljama i prakticiziranje njihove vlastite religije i običaja pod uvjetom da plaćaju poreze. Ta komercijalna fleksibilnost islama imala je utjecaja na kreiranje fleksibilnijih odnosa kršćanstva prema ratnim običajima i moralnom kodeksu u doba ratnih zbivanja. Pod utjecajem islamskog prava kršćanstvo je prihvatilo je arbitražu s nekršćanskim zemljama u ratnom sukobu.

\subsection{Ugovori o ratnim ograničenjima}

Saglasno Kuranu ugovori o ratnim ograničenjima koji su bili potpisani s neislamskim zemljama morali su biti striktno poštivani, sve dok ne budu prekršeni od strane nemuslimana, što je po pravilu vodilo u ratne sukobe i oslobađanje svake odgovornosti islamskog imperija da povede rat protiv zemlje koja je prekršila odredbe ugovora. Stanovništvo neislamske zemlje koja je prekršila ugovor o miru nije moglo biti prisiljeno prihvatiti islam nakon aneksije, što je notirano u brojnim odredbama Kurana. 
Bez prisiljavanja stanovništva pokorenih teritorija da prihvate islam, s uspostavljanjem mirnog odnosa s neislamskim zemljama, sa striktnim poštivanjem potpisanih ugovora s neislamskim zajednicama, s visokim stupnjem zaštite zarobljenika i ranjenika u oružanim sukobima, sa striktnom zaštitom žena i djece u ratnim sukobima, s uvođenjem arbitraže s nekršćanskim zemljama u ratnim sukobima, islam je izrastao u prihvatljiv, ne samo vjerski, nego isto tako i politički kodeks vrijednosti za brojne plemenske zajednice koje su se ubrzo našle u okrilju islama, što je imalo velik utjecaj na brzi raspad Bizanta, Abesinije i Perzije.

\subsection{Zaštita diplomatskih predstavnika u islamskom pravu}

Od najranijih dana islamske civilizacije diplomatski predstavnici uživali su imunitet od progona i suđenja, uživali su slobodu koja im je garantirala zaštitu od arbitrarnog uhićenja i pritvaranja, te uživali odgovarajuću zaštitu i odgovarajući tretman od strane islamske države, s njihovom obitelji i članovima diplomatske pratnje (Bassiouni, 1969, 163).

U Kuranu je razvijen koncept tzv. aman, kojim se garantira zaštita diplomatskomu predstavniku neislamskih zemalja, sve do njegova sigurnog napuštanja teritorija islamske države, koja se mora suzdržati od svakog nasilja prema diplomatskomu predstavniku, i poštivati sve privilegije koje su mu dodijeljene, kao i slobodu obavljanja njegovih vjerskih dužnosti. Diplomatski predstavnik ili emisar uživa pun imunitet i ne može biti kažnjen za ponašanje države koju predstavlja ili zastupa. Jedina mjera prema diplomatskomu predstavniku može biti protjerivanje u slučaju da se njegova država ili on sam ogriješi o pravila islama. Ubojstvo emisara smatra se u islamskom pravu, slično kao i u Lex Romana, kao pravedni temelj za vođenje pravednog rata (casus belli), što je i potvrđeno tzv. ugovorom Hudaibia (The Treaty of Hudaybiyya), koji je potpisan u Meki 628. godine. Ako je neislamski posrednik ili diplomatski predstavnik želio prihvatiti islam kao religiju, to nije mogao učiniti kao strani predstavnik ili posrednik, s čime je nepovredivost poslanika dobila na velikoj važnosti (Bassiouni, 1969, 162-164).

Brojni povjesničari islamskog prava potvrđuju apsolutnu zaštitu imuniteta diplomatskih predstavnika u islamskom pravu, koja je izvedena direktno iz Kurana i razvijana u praksi poslanika Muhameda, koja isključuje krivičnu i građansku jurisdikciju države u odnosu na diplomatske predstavnike ili posrednike između država, osim u slučaju hudud kriminala: theft, fornication, consumption of alcohol, and apostasy (Hamidullah, 1996, 134-144).

Kako zaštita posrednika ili diplomatskih predstavnika u islamskom pravu proistječe izravno iz božanskog prava, dakle iz Kurana i Hadisa/Sune, taj se oblik zaštite ne može derogirati ugovorima koji se zaključuju između država. Primjena reciprociteta u ponašanju prema diplomatskom predstavniku dozvoljena je $u$ islamskom pravu. 


\subsection{Ratna ograničenja u islamskom pravu}

U skladu s islamskim ratnim pravom upotreba sile ograničena je samo na pojedince koji direktno sudjeluju u ratnom vojnom djelovanju i neprijateljstvima na vojnom polju. Iz ranog razdoblja razvoja islamske civilizacije postoje brojne instrukcije izdane izravno od poslanika Muhameda i njegovih nasljednika koje se odnose na ponašanja u ratu (Al-Dawoody, 2011).

Posebna zaštita po islamskom ratnom pravu osigurana je za medicinsko osoblje u uvjetima kada pruža medicinske usluge neprijateljskoj vojsci. Zaštita od egzekucije štitila je i stare vojnike i stare osobe koje ne mogu zbog starosti sudjelovati u ratnom vojnom djelovanju.

U skladu s ranim islamskim ratnim pravom, uporaba sile u ratu i izvođenje vojnog djelovanja moglo se je poduzeti samo po odobrenju imama, odnosno legitimne vlasti islamske države. Isto se je odnosilo i na proglašavanje neprijateljstva, koje je moglo biti proglašeno samo i isključivo odlukom nadležne vlade islamske zemlje. Nema neprijateljstva ni rata bez službene inicijative i odluke islamske vlasti.

Pitanje otpočinjanja i vođenja džihada izazivalo je veliku raspravu među islamskim pravnicima. Jedna grupa islamskih pravnika, na čelu s Imamom Abu Jusufom (Abu Yusuf Ya'qub b. Ibrahim al-Ansari, oko 731.-798.), smatrala je da je objavljivanje i vođenje džihada isključivo u nadležnosti islamske države, odnosno vlade islamske države. Samo je nadležna vlada islamske države mogla odlučiti hoće li se i kada voditi džihad, što je imalo značenje ograničenja otpočinjanja i vođenja "svetog rata", koji se nije mogao voditi bez valjane odluke islamske vlade (Calder, 1993, 1-257).

Međutim, druga grupa islamskih pravnika, na čelu s imamom Kulanijem (Muhammad ibn Ya'qūb al-Kulayn), priznatim autoritetom i velikim pravnikom u shia učenju (Shia fiqh - Fiqh Jafari), smatrala je da se objava džihada ne mora uvijek objavljivati u prisustvu, odnosno uz dopuštenje islamske vlade, odnosno imama ili njegova predstavnika (Meri, 2005).

Rano islamsko pravo posebno oštro kažnjava svaku vrstu izdaje, što je naglašeno u Kuranu, gdje se svaka izdaja, čak i izdaja neprijatelja oštro zabranjuje. Oštro se zabranjuje kršenje mirovnih ugovora s neprijateljskom stranom. Odmah po okončanju ratnih događanja ratni zarobljenici moraju se osloboditi ili razmijeniti uz otkupninu (ransom) (Qur'an, 47:4). Zaključivanje ugovora o neutralnosti dopušteno je po islamskom ratnom pravu i bilo je često prakticizirano u doba širenja velikog islamskog imperija. Poznati su sporazumi o neutralnosti sklopljeni s Armenijom, Ciprom i Etiopiom.

\section{Zaključak}

U međunarodnom islamskom javnom pravu (Siyar) najizoštrenije se reflektira odnos između "Božje suverenosti” i "idealne interpretacije Božje suverenosti”, što čini najveću pravnu kontradikciju u islamskoj jurisprudenciji danas. 
Ta pravna kontradikcija u islamskom pravu, koja je opterećena potencijalnom mogućom ljudskom greškom ili namjerom, kreira novi pravni konflikt u procesu primjene šerijetskih zakona u praksi - Fikh, što dodatno otvara pitanje prirode islamskog ratnog prava, a to u doba globalnog rata protiv terorizma čini tu granu islamskog prava izuzetno problematičnom.

Taj tripartitni potencijalni pravni konflikt otvara u modernoj islamskoj jurisprudenciji veliki politički problem, koji se najčešće reflektira kao "zatvoreni krug nasilja" između države i društva u islamu, sa snažnim refleksijama na odnose između islama i drugih civilizacija. Taj hipotetički pravni konflikt između Božjeg suvereniteta (Kuran, Hadis, Suna), idealne interpretacije Božjeg suvereniteta (šerijat) i implementacije šerijatskih zakona (Fiqh), koje primjenjuje država, vodi u sve izraženiji unutarnji konflikt u islamu između države (vladara) i čovjeka (društva), kao agenata Božjeg suvereniteta na zemlji, što pitanje demokracije u islamu čini izuzetno konfuznim i konfliktnim. Zato po jednom pravnom mišljenju (pravna škola themukhatti'ah) pravo koje primjenjuje država samo je potencijalno Božje pravo, što će biti određeno tek na sudnjem danu. Po drugom pravnom mišljenju (pravna škola musawwibah) pravo koje primjenjuje država nije Božje pravo sve dok osoba na koju se primjenjuje zakon ne smatra da je to Božja volja i naredba. Ostaje otvorenim pitanje je li rješenje tog hipotetičkog pravnog sukoba moguće tražiti u otvaranju unutarnjeg dijaloga između države (vladara) i društva (naroda) kao agenata Božjeg suvereniteta na zemlji, čime bi bile otvorene šire mogućnosti smirivanja političkih konfrontacija u islamskom svijetu iz kojih izrasta "zatvoreni krug nasilja”, koji s pravom ili ne, nosi prefix "islamski”.

\section{Literatura:}

Al-Dawoody, Ahmed (2011). The Islamic Law of War: Justifications and Regulations. New York: Palgrave Macmillan.

Al-Mawardi, Muhammad Ibn Habib (1996). The Laws of Islamic Governance: al-Ahkam as-Sultaniyyah. London: United Kingdom.

Al-Shafi' ‘, Muhammad ibn Idrīs (2001). Kitāb al-Umm. S. 1.: Dar al-Wafa'.

Al-Tabari, Muhammad ibn Jarir (1992). The History of al-Tabari: Ta'rikh al rusul wa'l-muluk: Vol. 12. Na engleski prevela Yohanan Friedman. Albany: State University of New York.

Al-Zarqa, Mustafa Ahmad (1968). Al-Madkhal Al-Fiqhi Al-Aam. Vol. II. Damask: Dar al-Fikr.

Athamina, Khalil (1999). The Pre-Islamic Roots of the Early Muslim Caliphate: The Emergence of Abū Bakr. Der Islam, 76(1), 1-32-

Bassiouni, M. Cherif (1969). Islam: Concept, Law and World Habeas Corpus. Camden: Rutgers Universy.

Calder, Norman (1993). Studies in Early Muslim Jurisprudence. Oxford: Clarendon.

Cook, Michael Allan (2000). Commanding Right and Forbidding Wrong in Islamic Thought. Cambridge: Cambridge University.

El Fadl, Khaled Abou (2001). Rebellion and Violence in Islamic Law. Cambridge: Cambridge University.

El Fadl, Khaled Abou (2002). The Place of Tolerance in Islam. Boston: Beacon. 
El Fadl, Khaled Abou (2003). Islam and the Challenge of Democratic Commitment. Fordham International Law Journal, 27(1), 4-71.

Ghazi, Mahmood Ahmad, Khutbat-i-Bahāwalpur II: Islām kā Qānūn Bayn al-Mamālik., Policy Perspectives, Volume6, Number1, January — June 2009, Institute for Policy Studies, Islamabad

Ghazi, Mahmood Ahmad (2006). The Contribution of Islamic Law to the Emergence of International Humanitarian Law. Research Papers, Vol. VI. No. 1-2, str. 699-722, ISSN 1512-648X, University of Bihać

Hamidullah, Muhammad (1996). The Muslim Conduct of State. Lahore: Sh. Muhammad Ashraf.

Harle, Vilho (1998). Ideas of Social Order in the Ancient World. Santa Barbara: Greenwood.

Ibn Khaldūn (1958). The Muqaddimah: An Introduction to History. New York: Pantheon Books

Kallāf, Abd al-Wahhāb (1978). Ilm Usül al-Fiqh. Mesir.

Khadduri, Majid (1979). War and Peace in Law of Islam. New York: AMS.

Khadduri, Majid (1996). The Islamic Law of Nations: Shaybani's Siyar. Baltimore: The Johns Hopkins.

Lewis, Bernard (2005). Freedom and Justice in the Modern Middle East. Foreign Affairs, 84(3), 36-51.

Meri, Josef W. (2005). Medieval Islamic Civilization: An Encyclopedia. USA: Routledge.

Peters, Rudolph (1996). Jihad in Classical and Modern Islam. Princeton: Markus Wiener.

Pictet, Jean (1985). Development and Principles of International Humanitarian Law. Berlin: Springer.

Qur'an. English Translation of the Holy Quran: by Maulana Muhammad Ali. URL: http:// www.aaiil.org/text/hq/trans/ma_list.shtml (29.11.2018.)

Schacht, Joseph (1959). The Origins of Muhammadan Jurisprudence. Oxford: Oxford University.

Shaw, Stanford Jay (2006). The Ottoman Empire in World War I. Ankara: Yayinlan.

Smock, David R. (2004). Ijtihad: Reinterpreting Islamic Principles for the Twenty-first Century. Washington, DC: United States Institute of Peace.

Uthman, Muhammad Rafat (1983). Al-Huquq wa-al-Wājibāt wa-al-'Alaqāt alDuwalyyiah figh al-Islam. Kairo.

Walsh, Edmund A. (ur.) (1922). The History and Nature of International Relations. New York: Macmillan.

Webster, David (1975). Warfare and the Evolution of the State: A Reconsideration. American Antiquity, 40(4), 464-470.

Weeramantry, Christopher G. (1988). Islamic Jurisprudence: An International Perspective. New York: Macmillans. 
Ius ad bellum \& ius in bello in Early Islamic Civilization

Nedžad Bašić*

Summary

The contemporary legal and political debate on Islamic law is, for the most part, related to global violence and studied within the matrix of global Islamic terrorism. In these academic and political discussions, the ascertaining of violence in Islam is done mainly in relation to Islamic law-Shari'ah and Fiqh- which are not part of divine Islamic law, but primarily legal rules established through the interpretation of divine Islamic law by God's human agent on earth. The interpretation of divine law by a human agent can lead to error in interpretation and application of its norms, particularly in regard to the Islamic law of war. The potential legal conflict between the norms of Islamic divine law and their human interpretation can produce a high level of legal confusion which could lead to political turmoil in Islamic countries. Due to the effects of the constant internal social and political reforms of Islam and the external influences of powerful early non-Islamic civilizations, the norms of the Islamic law of war are constantly and increasingly becoming more flexible in their meaning and interpretation.

The norms of the Islamic law of war have been acquiring a different meaning, not without major political implications, since the early period of Islamic development until today, particularly in the teachings of numerous legal schools such as: Hanafi, Hanbal, Maliki and Shafi'i within Sunni Islam and Jafari within Shia Islam, and in the teachings of famous Islamic jurists (Abu Bakr, al-Mawardi, Abu Hanifah, Al Shafi, Muhammad al Shaybani, al-Kulaynī Al-Rāzī, Al-Tabari..). Also, the rules of Islamic law of war, as part of the Islamic legal system (haqq), can gain a different meaning in decision-making processes (shura) by using consensus (ijma), consultation, inventiveness (talfiq), and analogy of the Quranic verses (kiyas), as a method of understanding Islamic law, in theological (mujtahid) interpretations of the Qur'an.

Key words: Akham al-Hiraba, Akham al-Bughat, Akham al-Tariq

* Nedžad Bašić, Ph.D., Human Rights Conflict Prevention Centre, Faculty of Law, University of Bihać. Address: Ul. Mehe Hadžiabdića bb, 77000 Bihać, Bosnia and Herzegovina E-mail: nbasic.hrcpc@gmail.com 